УДК 58.1: [661.162.6:582.707]

doi: $10.25128 / 2078-2357.19 .3 .9$

Г. С. ШАТАЛЮК, В. Г. КУР’ЯТА

Вінницький державний педагогічний університет імені М. Коцюбинського

вул. Острозького, 32, Вінниця, 21000

e-mail: halya17061991@gmail.com

\title{
ВПЛИВ ЕСФОНУ НА БІОХІМІЧНІ ЗМІНИ В ПЕРІОД ДОЗРІВАННЯ ЯГІД, УРОЖАЙНІСТЬ ТА ЯКІСТЬ ПЛОДІВ АГРУСУ
}

Досліджено вплив передзбиральної обробки кущів агрусу (Grossularia reclinata (L.) MILL) сорту Машенька 0,3\%-им водним розчином етиленпродуценту есфону на урожайність та якісні характеристики ягід, кількісні зміни вмісту структурних полісахаридів у процесі дозрівання плодів.

Встановлено, що на четвертий, восьмий і дванадцятий день у ягід рослин, оброблених етиленпродуцентом, уміст відновлюючих цукрів, сахарози та їх суми був вищим порівняно 3 контролем. Виявлено інтенсивніше зниження загальної кислотності ягід дослідного варіанту, при цьому вміст аскорбінової кислоти достовірно не змінювався. Зафіксованоно також вищу активність амілази в ягодах за дії етиленпродуцента в період їх дозрівання, унаслідок чого відбувалося більш швидке зниження вмісту крохмалю та збільшення кількості в них цукрів. Передзбиральне обприскування етиленпродуцентом призводило до зменшення вмісту структурних полісахаридів та до суттєвого зростання вмісту пектинів. Зроблено висновок про перспективність застосування есфону у насадженнях агрусу 3 метою прискорення i синхронізації дозрівання плодів, покращення їх якості.

Ключові слова: атрус, етиленпродуценти, полісахариди, дозрівання ягід, мачерація, якість плодів.

Застосування речовин, які після обприскування рослин розпадаються з виділенням етилену, відкриває широкі перспективи використання їх в практиці рослинництва для прискорення дозрівання плодів, механізованого збору продукції $[3,13]$. Препарати можна застосовувати і для післязбиральної обробки плодів з метою прискорення їх дозрівання та покращення окрасу $[2,12]$.

Встановлено, що дозрівання плодів ягода супроводжується глибокою структурною i функціональною перебудовою клітинної стінки: зменшенням іiі товщини [9], посиленням активності ферментів, що руйнують полісахариди [18], значними змінами геміцелюлоз і співвідношення протопектинів: розчинний пектин, деполімеризацією пектинів [19], розщепленням глікопротеїнового комплексу серединних пластинок [5]. Зміни у клітинній стінці ведуть до зменшення твердості плоду, покращення його технологічних якостей $[4,16]$.

Дозрівання плоду не можна розглядати тільки як деструктивний процес. У цей час активується синтез ряду білків, утворюється ферментна система синтезу етилену, підвищується активність полігалактуронази, пектинестерази, целюлази, рибонуклеази, поліфенолоксидази, пероксидази, відбувається збільшення кількості мітохондрій та рибосом $[1,17]$.

Разом 3 тим, фізіологічні та біохімічні зміни в плодах ягода після обробки їх етиленпродуцентами залишаються значною мірою ще маловивченими, що обмежує практичне застосування зазначених препаратів. У зв'язку з цим, метою дослідження було встановити зміни в накопиченні різних форм цукрів, загальної кислотності та аскорбінової кислоти, структурі полісахаридного комплексу ягід агрусу в процесі їх дозрівання після передзбиральної обробки рослин етиленпродуцентом есфоном.

\section{Матеріал і методи досліджень}

Роботу проводили на насадженнях рослин агрусу (Grossularia reclinat (L.) MILL) сорту Машенька у спеціалізованому господарстві ФГ «Дагор» с. Раково Томашпільського p-ну Вінницької обл. у вегетаційні періоди 2015-2017 pp. Розташування дослідних ділянок рендомізоване, у ряді п'ять кущів, повторність польового досліду п'ятикратна. Рослини 
обробляли 0,3\%-им водним розчином есфону за 10 днів до збирання ягід за допомогою ранцевого обприскувача ОП-2 [8]. Обробку проводили одноразово в середині дня.

Контрольні рослини обробляли водопровідною водою. Ягоди для аналізу відбирали через кожні чотири дні після обробки рослин препаратом. Уміст полісахаридів визначали на фіксованому матеріалі - ягоди фіксували в польових умовах рідким азотом, досушували в сушильній шафі при температурі $70^{\circ} \mathrm{C}$ до повітряно-сухого стану. Визначення вмісту целюлози та пектинів здійснювали ваговим методом, вмісту геміцелюлоз та неструктурних вуглеводів (цукрів і крохмалю) у плодах агрусу - проводили йодометричним методом [15]. У процесі дозрівання визначали активність інвертази та амілази за Х. М. Починком [11]. Для оцінки якості ягід проводили їх аналіз на загальну кислотність шляхом потенціометричного титрування [6], вміст аскорбінової кислоти визначали за допомогою гексаціаноферату калію [14].

Аналітична повторюваність досліджень - п’ятикратна. Статистичну обробку результатів здійснювали за допомогою комп'ютерної програми «Statistica-6». Достовірність різниці показників контролю і досліду визначали за t-критерієм Стьюдента. У таблицях і на рисунку представлені середньоарифметичні значення та їх стандартні похибки за три роки досліджень.

\section{Результати досліджень та їх обговорення}

Передзбиральна обробка кущів агрусу розчином есфону спричиняла зростання урожайності (контроль $-3,0 \pm 0,03$ кг, есфон - 3,2 $\pm 0,04$ кг з куща), а також впливала на якісний склад ягід (табл. 1).

Встановлено, що на четвертий, восьмий і дванадцятий день після обробки рослин етиленпродуцентом у ягодах уміст відновлюючих цукрів, сахарози та їх суми був вищим порівняно 3 контролем. Зафіксоване інтенсивніше зменшення загальної кислотності ягід дослідного варіанту, при цьому вміст аскорбінової кислоти достовірно не змінювався. Збільшення вмісту цукрів та зниження загальної кислотності плодів під впливом етиленпродуценту кампозану виявлено нами також в аналогічних дослідженнях, проведених раніше з культурою малини [7].

Таблиия 1

Зміни якісних показників ягід агрусу в процесі їх дозрівання за дії есфону

\begin{tabular}{|c|c|c|c|c|c|c|}
\hline \multirow{2}{*}{ Показник } & \multicolumn{3}{|c|}{ Контроль } & \multicolumn{3}{c|}{ Есфон } \\
\cline { 2 - 7 } & I & II & III & I & II & III \\
\hline $\begin{array}{c}\text { Сума цукрів, \% на масу } \\
\text { сирої речовини }\end{array}$ & $6,0 \pm 0,2$ & $6,2 \pm 0,2$ & $7,1 \pm 0,3$ & $6,1 \pm 0,2$ & $7,9 \pm 0,2^{*}$ & $8,9 \pm 0,3^{*}$ \\
\hline $\begin{array}{c}\text { Відновлюючі цукри, \% на } \\
\text { масу сухої речовини }\end{array}$ & $4,7 \pm 0,1$ & $4,5 \pm 0,1$ & $5,2 \pm 0,1$ & $5,2 \pm 0,1$ & $6,1 \pm 0,1^{*}$ & $6,8 \pm 0,3^{*}$ \\
\hline $\begin{array}{c}\text { Сахароза, \% на масу сирої } \\
\text { речовини }\end{array}$ & $1,3 \pm 0,1$ & $1,6 \pm 0,1$ & $1,80 \pm 0,1$ & $1,2 \pm 0,1$ & $1,7 \pm 0,1 *$ & $2,0 \pm 0,1^{*}$ \\
\hline $\begin{array}{c}\text { Крохмаль, \% на масу сирої } \\
\text { речовини }\end{array}$ & $0,85 \pm 0,01$ & $0,45 \pm 0,03$ & $0,32 \pm 0,01$ & $0,71 \pm 0,02$ & $0,39 \pm 0,01 *$ & $0,27 \pm 0,02$ \\
\hline $\begin{array}{c}\text { Вміст аскорбінової } \\
\text { кислоти, мг/100г }\end{array}$ & $21,2 \pm 0,6$ & $21,0 \pm 0,6$ & $20,8 \pm 0,4$ & $21,5 \pm 0,6$ & $22,7 \pm 0,7$ & $22,4 \pm 0,7$ \\
\hline $\begin{array}{c}\text { Титрована кислотність, \% } \\
\text { на масу сирої речовини }\end{array}$ & $2,23 \pm 0,06$ & $1,96 \pm 0,04$ & $1,84 \pm 0,05$ & $2,01 \pm 0,06$ & $1,72 \pm 0,04 *$ & $\begin{array}{c}1,82 \pm 0,05 \\
*\end{array}$ \\
\hline
\end{tabular}

Примітка: дні після обробки: I - 4-й день; II - 8-й день; III - 12-й день;

* - різниця достовірна при $\mathrm{p} \leq 0,05$

Виявлено незначне зростання активності інвертази в ягодах агрусу протягом їх дозрівання за впливу есфону, однак достовірна різниця між контролем і дослідним варіантами була відсутня (рисунок). 


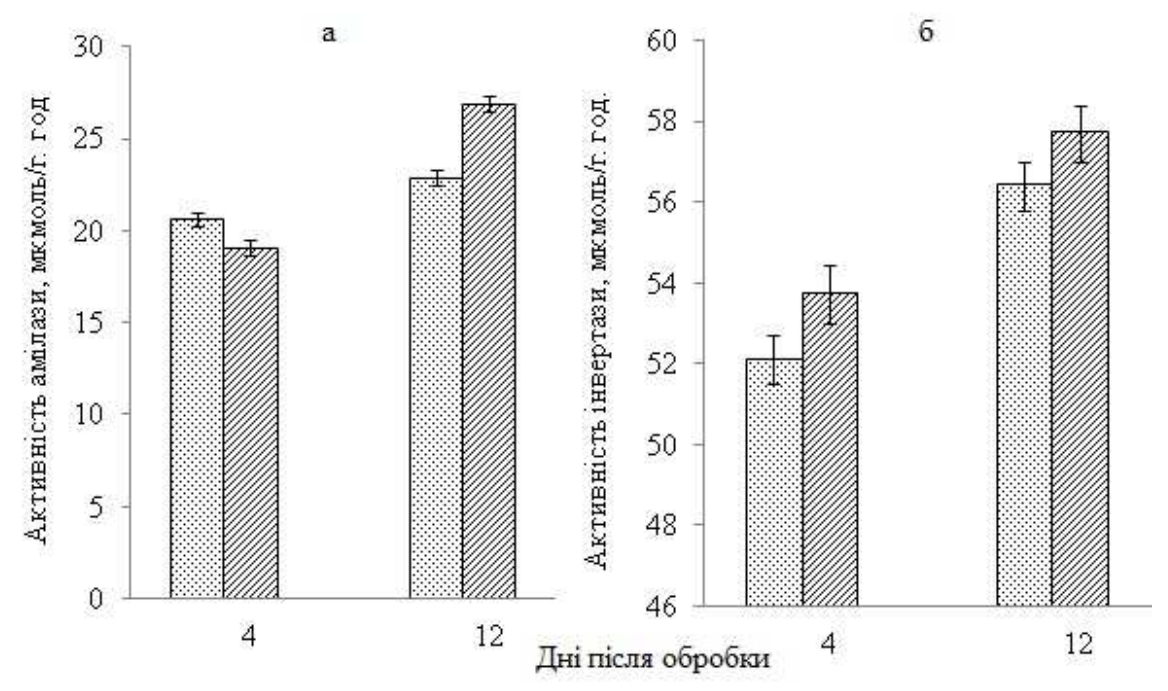

Рисунок. Дія есфону на активність амілази (а) та інвертази (б) в процесі дозрівання ягід агрусу сорту Машенька;, - контроль;

Встановлено також вищу активність амілази в ягодах агрусу сорту Машенька за дії етиленпродуцента в період їх дозрівання, чим, очевидно, і пояснюється більш швидке зменшення вмісту крохмалю в плодах та збільшення кількості в них цукрів.

Відомо, що ступінь солодкості ягід визначається співвідношенням цукри / органічні кислоти. Як свідчать отримані результати, зазначене співвідношення швидше зростає за умови застосуванням есфону.

Стиглість ягід значною мірою визначається інтенсивністю мацерації рослинних тканин, яка починається з перетворень полісахаридного комплексу клітинних стінок $[1,7]$. Відомо, що процес дозрівання соковитих плодів супроводжується збільшенням вмісту водорозчинних пектинів, зміною активності ферментів їх обміну та полімерних характеристик. Зокрема, у томатах при переході зеленого плоду до споживчої зрілості активність пектинестерази зростала у 20 разів. Активність полігалактуронази не вдалося виявити у зелених плодів, але вона була надзвичайно високою у зрілих ягодах томатів [1]. Проведене нами раніше визначення молекулярної маси пектинів, виділених $з$ плодів малини протягом тижня після обробки насаджень $0,1 \%$-им розчином кампозану М, показало, що поліуронідний комплекс піддається значним змінам: при дозріванні плодів знижувалася молекулярна маса пектинових речовин, причому за дії етиленпродуцента процес відбувався швидше [7].

Отримані результати свідчать про суттєві зміни полісахаридного комплексу клітинних стінок ягід агрусу при застосуванні передзбиральної обробки етиленпродуцентом (табл. 2).

Таблиия 2

Вміст структурних полісахаридів в ягодах агрусу під впливом есфону в процесі дозрівання (\% на масу сухої речовини)

\begin{tabular}{|c|c|c|c|c|c|c|}
\hline \multirow[b]{2}{*}{ Показник } & \multicolumn{3}{|c|}{ Контроль } & \multicolumn{3}{|c|}{ Есфон } \\
\hline & 4-й день & 8-й день & 12-й день & 4-й день & 8-й день & 12-й день \\
\hline Пектини & $11,9 \pm 0,2$ & $15,1 \pm 0,3^{*}$ & $19,7 \pm 0,4^{*}$ & $13,4 \pm 0,3$ & $17,4 \pm 0,4 *$ & $22,6 \pm 0,5^{*}$ \\
\hline Целюлоза & $17,4 \pm 0,4$ & $16,2 \pm 0,2 *$ & $15,4 \pm 0,2 *$ & $16,1 \pm 0,3$ & $14,6 \pm 0,6^{*}$ & $14,0 \pm 0,4^{*}$ \\
\hline Геміцелюлози & $17,6 \pm 0,5$ & $16,6 \pm 0,4 *$ & $16,3 \pm 0,4 *$ & $17,1 \pm 0,4$ & $16,7 \pm 0,5^{*}$ & $16,1 \pm 0,4^{*}$ \\
\hline
\end{tabular}

Примітка: * - різниця достовірна при $\mathrm{p} \leq 0,05$.

Аналіз вмісту пектинів в ягодах агрусу протягом періоду дозрівання свідчить про суттєве зростання кількості зазначеного полісахариду, причому за дії есфону його накопичення відбувалося інтенсивніше. Раніше було також встановлено, що обробка рослин малини перед збиранням урожаю етиленпродуцентом кампозаном спричинила розщеплення 
високомолекулярних фракцій целюлози первинних стінок, що сприяло більш швидкій мацерації плодів [7].

Отримані результати дослідження свідчать, що передзбиральне застосування есфону призводить до зменшення вмісту целюлози в ягодах агрусу: у дослідному варіанті зменшення вмісту цього структурного полісахариду відбувалося інтенсивніше. Це узгоджується 3 отриманими нами раніше даними, що під впливом етиленпродуцентів активується розщеплення низькомолекулярних фракцій целюлози первинних клітинних стінок плодів малини, що забезпечує прискорення мацерації тканин [7]. Можна висловити припущення, що частковий гідроліз целюлози при дозріванні плодів призводить до поповнення в них умісту цукрів.

Відомо, що геміцелюлози виконують не лише структурну функцію в клітині, а можуть частково використовуватися як резервна речовина [10]. Результати дослідження свідчать про зменшення вмісту геміцелюлоз при дозріванні ягід, але достовірних відмінностей між контролем і дослідом не встановлено.

\section{Висновки}

Отже, передзбиральна обробка ягід агрусу етиленпродуцентом есфоном призводить до посилення накопичення пектинових речовин у плодах, інтенсивнішого гідролізу целюлози у порівнянні з контролем, що $\epsilon$ важливими показниками більш ранньої мацерації тканин ягід. За дії препарату в ягодах інтенсивніше накопичувалися всі форми цукрів та швидше зменшувалася загальна кислотність. Установлено, що за дії препарату прискорювалося розщеплення крохмалю ягід внаслідок зростання активності амілази. Застосування передзбиральної обробки ягід агрусу етиленпродуцентом есфоном призводило до зростання урожайності культури агрусу, покращення якості продукції.

1. Бертон У.Г. Физиология созревания и хранения продовольственных культур. Москва: Агропромиздат, $1985.359 \mathrm{c}$.

2. Буланцева Е. А., Н Нгуен Тьен Тханг, Ружицкий А. О., Проценко М. А., Кораблева Н. П. Влияние регуляторов биосинтеза этилена на метаболические процессы в плодах банана разной степени зрелости. Прикладная биохимия и микробиология. 2009. Т. 45, № 1. С. 104-108.

3. Дерфлинг К. Гормоны растений. Системный подход. Москва: Мир, 1985. 303 с.

4. Землянская Е. В., Омельянчук Н. А., Ермаков А. А., Миронова В. В. Механизмы регуляции передачи этиленового сигнала у растений. Вавиловский журнал генетики и селекции. 2016. Т. 20, № 3. С. 386395 DOI:10.18699/VJ15.105

5. Кахана Б. М., Кривилева Н. И. Превращения гликопротеинового комплекса клеточных стенок при размягчении плодов. Теоретическая и прикладная карпология: тези Всесоюзної конференції. Кишинев: Штиинца. 1989. С. 123-124.

6. Крищенко В. П. Методы оценки качества растительной продукции. Москва : Колос, 1983. 192 с.

7. Кур'ята В. Г. Фізіолого-біохімічні механізми дії ретардантів і етиленпродуцентів на рослини ягідних культур: дис. ... д-ра біол. наук : 03.00.12. Київ, 1999. 318 с.

8. Кур'ята В. Г., Попроцька І. В. Фізіолого-біохімічні основи застосування ретардантів в рослинництві: монографія. Вінниця : ТОВ «Твори», 2019.98 с.

9. Метлицкий Л. В. Иммунологический контроль в жизни растений. Москва : Наука, 1987. 68 с .

10. Попроцька I. В. Регуляція донорно-акцепторних відносин у рослин в системі «депо асимілятів ріст» у процесі проростання: монографія. Вінниця: Нілан-ЛТД, 2017. 123 с.

11. Починок Х. Н. Методы биохимического анализа растений. Киев : Наук. думка, 1976. 334 c.

12. Причко Т. Г., Германова М. Г., Смелик Т. Л. Усиление интенсивности окраски яблок регуляторами роста в период выращивания. Научные труды гос. науч. учреждения Северо-Кавказского зонального науч.-исслед. ин-та садоводства и виноградарства Рос. акад. с.-х. наук. 2015. Т. 8. С. 153-158.

13. Проценко М., Буланцева Е., Ружицкий А., Хотченков В. Застосування сполук, які після обприскування рослин розпадаються 3 виділенням етилену, відкриває широкі перспективи використання їх в практиці рослинництва для прискорення дозрівання плодів і ягід, механізованого збору продукції. С.-х. биол. 2013. № 3. С.14-19. 
14. Щипарев С. М. Количественное определение аскорбиновой кислоты с помощью гексацианоферрита калия. Методь биохимического исследования растений. Л. : Из-во Ленинградского ун-та. 1978. C. $133-135$.

15. AOAC. Official Methods of Analysis of Association of Analytical Chemist International 18th ed. Rev. 3. 2010. Asso of Analytical Chemist. Gaithersburg, Maryland: USA, 2010. 700 p.

16. Ding S., Wang R., Shan Y., Li G. Changes in pectin characteristics during the ripening of jujube fruit: Changes in pectin characteristics during jujube fruit ripening. Journal of the Science of Food and Agriculture. 2017. Vol. 97, No 12. P. 4151-4159. DOI: 10.1002 / jsfa.8285

17. Gustavo D. Trinchero, Trincheroa, Gabriel O. Sozzia, Ana M. Cerri, Fernando Vilella, Adela A. Fraschina. Ripening-related changes in ethylene production, respiration rate and cell-wall enzyme activity in goldenberry (Physalis peruviana L.), a solanaceous species. Postharvest Biology and Technology. 1999. Vol 16, No 2. P. 139-145. DOI: 10.1016/S0925-5214(99)00011-3

18. Kausik M., Bibhas M. Ethephon induced fractional changes of pectic polysaccharides in developing cape gooseberry (Physalis peruviana L) fruits. Journal of the Science of Food and Agriculture. 2005. Vol. 85, No 7. P. 1222-1226. DOI: 10.1002/jsfa.2090

19. Majumder K., Mazumdar B. C. Changes of pectic substances in developing fruits of cape-gooseberry (Physalis peruviana L.) in relation to the enzyme activity and evolution of ethylene. Scientia Horticulturae SCI HORT-AMSTERDAM. 2002. Vol. 96, No 1. P. 91-101. DOI:10.1016 / S0304-4238 (02) 00079-17.

\section{References}

1. Berton U. G. Fiziologiia sozrevaniia i khraneniia prodovol'stvennykh kul'tur./ Moskva: Agropromizdat, 1985. 359 s. ( in Russian).

2. Bulantseva E. A., Nguen T'en Tkhang, Ruzhitskiy A. O., Protsenko M. A., Korableva N. P. Vliianie reguliatorov biosinteza etilena na metabolicheskie protsessy $\mathrm{v}$ plodakh banana raznoy stepeni zrelosti. Prikladnaia biokhimiia i mikrobiologiia. 2009. T. 45. No 1. S 104-108. (in Russian).

3. Derfling K. Gormony rasteniy. Sistemnyy podkhod / Moskva: Mir, 1985. 303 s. (in Russian).

4. Zemlianskaia E. V., Omel'ianchuk N. A., Ermakov A. A., Mironova V. V. Mekhanizmy reguliatsii peredachi etilenovogo signala u rasteniy. Vavilovskiy zhurnal genetiki i selektsii. 2016. T. 20. No3. S. 386395 DOI:10.18699/VJ15.105. (in Russian).

5. Kakhana B. M., Krivileva N. I. Prevrashcheniia glikoproteinovogo kompleksa kletochnykh stenok pri razmiagchenii plodov. Teoreticheskaia i prikladnaia karpologiia: Tez. Vsesoiuz. konf. - Kishinev: Shtiintsa. 1989. S. 123-124. (in Russian).

6. Krishchenko V. P. Metody otsenki kachestva rastitel'noy produktsii. Moskva: Kolos. 1983, 192 s. (in Russian).

7. Kuryata V. H. Fizioloho-biokhimichni mekhanizmy dii retardantiv i etylenprodutsentiv na roslyny iahidnykh kul'tur : dys. ... doktora biol. nauk : 03.00.12 / Kuryata Volodymyr Hryhorovych. - K., 1999. 318 s. (in Ukrainian).

8. Kuryata V. H., Poprots'ka I. V. Fizioloho-biokhimichni osnovy zastosuvannia retardantiv v roslynnytstvi: monohrafiia / Vinnytsia. TOV «Tvory», 2019. 98 s. (in Ukrainian).

9. Metlitskiy L. V. Immunologicheskiy kontrol' v zhizni rasteniy. - Moskva: Nauka. 1987, 68 s. (in Russian).

10. Poprots'ka I. V. Rehuliatsiia donorno-aktseptornykh vidnosyn u roslyn v systemi «depo asymiliativ - rist» $\mathrm{u}$ protsesi prorostannia: monohrafiia. Vinnytsia: Nilan-LTD,. 2017. 123 s. (in Ukrainian).

11. Pochinok Kh. N. Metody biokhimicheskogo analiza rasteniy. Kiev: Nauk. dumka. 1976, 334 s. (in Russian).

12. Prichko T. G., Germanova M. G., Smelik T. L. Usilenie intensivnosti okraski iablok reguliatorami rosta v period vyrashchivaniia. Nauchnye trudy gos. nauch. uchrezhdeniia Severo-Kavkazskogo zonal'nogo nauch.issled. in-ta sadovodstva i vinogradarstva Ros akad. s.-kh. nauk. 2015. T. 8. S. 153-158. (in Russian).

13. Protsenko M., Bulantseva E., Ruzhitskiy A., Khotchenkov V. Zastosuvannia spoluk, iaki pislia obpriskuvannia roslin rozpadaiut'sia $\mathrm{z}$ vidilenniam etilenu, vidkriva€ shiroki perspektivi vikoristannia ïkh $\mathrm{v}$ praktitsi roslinnitstva dlia priskorennia dozrivannia plodiv i iagid, mekhanizovanogo zboru produktsiï. S.kh. biol.. 2013. No 3. S.14-19. (in Russian).

14. Shchiparev S. M. Kolichestvennoe opredelenie askorbinovoy kisloty s pomoshch'iu geksatsianoferrita kaliia. Metody biokhimicheskogo issledovaniia rasteniy. - L.: Iz-vo Leningradskogo un - ta. 1978. S. 133135. (in Russian).

15. AOAC. Official Methods of Analysis of Association of Analytical Chemist International 18th ed. Rev. 3. 2010. Asso of Analytical Chemist. Gaithersburg, Maryland: USA, 2010. 700 p. 
16. Ding S., Wang R., Shan Y., Li G. Changes in pectin characteristics during the ripening of jujube fruit: Changes in pectin characteristics during jujube fruit ripening. Journal of the Science of Food and Agriculture. 2017. Vol. 97, No 12. P. 4151-4159. DOI: 10.1002 / jsfa.8285

17. Gustavo D. Trinchero, Trincheroa, Gabriel O. Sozzia, Ana M. Cerri, Fernando Vilella, Adela A. Fraschina. Ripening-related changes in ethylene production, respiration rate and cell-wall enzyme activity in goldenberry (Physalis peruviana L.), a solanaceous species. Postharvest Biology and Technology. 1999. Vol 16, No 2. P. 139-145. DOI: 10.1016/S0925-5214(99)00011-3

18. Kausik M., Bibhas M. Ethephon induced fractional changes of pectic polysaccharides in developing cape gooseberry (Physalis peruviana L) fruits. Journal of the Science of Food and Agriculture. 2005. Vol. 85, No 7. P. 1222-1226. DOI: 10.1002/jsfa.2090

19. Majumder K., Mazumdar B. C. Changes of pectic substances in developing fruits of cape-gooseberry (Physalis peruviana L.) in relation to the enzyme activity and evolution of ethylene. Scientia Horticulturae SCI HORT-AMSTERDAM. 2002. Vol. 96, No 1. P. 91-101. DOI:10.1016 / S0304-4238 (02) 00079-17.

\section{H. S. Shataliuk, V. G. Kuriata}

M. Kotsiubynskyi Vinnytsia State Pedagogical University, Ukraine

\section{THE INFLUENCE OF ESPHONE ON BIOCHEMICAL CHANGES DURING RIPENING PERIOD, YIELD, AND QUALITY OF GOOSEBERRY PRODUCTS}

The effect of pre-harvest treatment of gooseberry bushes (GROSSULARIA RECLINAT (L.) MILL) of cv. Mashenka with a $0.3 \%$ aqueous solution of ethylene product on the yield and quality characteristics of berries, quantitative changes in the content of structural polysaccharides during ripening were studied. The experiments were carried out in the field from 2015 to 2017. The experimental sites were randomly chosen, there were five bushes in a row, the repetition of the field experiment was fivefold. The plants were treated with $0.3 \%$ aqueous esphone two weeks prior to berry harvesting using an OP-2 backpack. The berries under analysis were selected every four days after treatment with the preparation. The polysaccharide content was determined on a fixed material. The berries were fixed in the field with liquid nitrogen, dried in a drying oven at $70^{\circ} \mathrm{C}$ to air - dry state. The determination of cellulose and pectin content was carried out by weight method, hemicellulose and non-structural carbohydrates (sugars and starch) in gooseberry fruits were carried out by iodometric method. To evaluate the quality of the berries, their analysis for total acidity was performed by potentiometric titration, ascorbic acid was determined using potassium hexacyanoferrate. The analytical replicability of the studies is fivefold. Statistical processing of the results was performed using the computer program 'Statistica-6'. The significance of the difference between the control and experiment indicators was determined by Student's t-test. It is found out that on the fourth, eighth and twelfth days, the content of reducing sugars, sucrose and their amounts in the berries treated with ethyleneproducer plants was higher than in the control sample. A more intense decrease in the total acidity of the berries of the experimental sample was observed, while the ascorbic acid content did not change significantly. A higher amylase activity in berries due to ethylene products during ripening was also established, resulting in a faster decrease in the starch content in the berries and an increase in the sugar content. Pre-harvesting of gooseberry with ethylene product esphone leads to increased accumulation of pectic substances in the products, a more intensive hydrolysis of structural polysaccharides in comparison with the control sample, which serves as an indicator of more intense maceration of fetal tissues. The use of pre-harvest processing of gooseberry with ethylene product esphone has led to increased yields and higher quality of gooseberry crop production and has many prospects for the development of mechanized harvesting technologies.

Key words: gooseberry, ethylene products, polysaccharides, ripening of berries, maceration, yield of production.

Надійшла 15.08.2019. 